\title{
Edition of Portuguese health journals and its relationship with their visibility: a quantitative analysis
}

\author{
Anabela Henriques ${ }^{1}$ \\ María Ángeles Zulueta García ${ }^{2}$
}

1. Coimbra Health School, Polytechnic Institute of Coimbra, Coimbra, Portugal 2. Department of Philology, Documentation and Audiovisual Communication, University of Alcalá, Madrid, Spain

http://dx.doi.org/10.1590/1806-9282.65.10.1290

\section{SUMMARY}

BACKGROUND: Scientific journals play a fundamental role in the field of health sciences, contributing not only to the dissemination of scientific results but also to the progress of medicine and the training of researchers. The visibility of scientific production in the health area is fundamental to the development of medicine. This study aimed to find the relationship between the editorial quality of a sample of Portuguese scientific health journals and their national and international visibility.

METHODS: This is an analytical, transversal and, essentially, quantitative study, based on the analysis of the compliance with Latindex editorial quality criteria in a sample of 46 scientific health journals and ascertaining their national and international visibility.

RESULTS: The research showed that the global average of compliance with the criteria by the sample of journals is $91 \%$. The average visibility of the sample is $24 \%$. The hypothesis that the editing criteria are related to the visibility of a sample of Portuguese health journals is confirmed.

CONCLUSION: Despite the high rate of compliance with editorial quality criteria, the international visibility of the journals analyzed is still scarce. This reveals the need for the development of complementary competences.

KEYWORDS: Periodicals as topic. Scientific and Technical Publications. Health. Portugal. Edition.

\section{INTRODUCTION}

Health scientific journals are fundamental to disseminate results of scientific research. The poor dissemination of research published in scientific journals leads to lack of recognition of the work of the authors who publish and, consequently, the invisibility of scientific research.

The quality of scientific journals is often associated with the databases on which they are indexed. ${ }^{1}$ When publishing results of scientific research, It is essential to choose a quality scientific journal, in- dexed in prestigious databases, which will proceed to conduct peer reviews and ensure the visibility of the work. Publication in what is known as "predatory journals" can have very negative effects on the career of researchers. These journals do not include a rigorous process of peer review and are not governed by standards of international quality. They are often open-access journals that charge the authors processing fees, alluring them with the publication of papers for profit. ${ }^{2}$ 
The visibility of scientific production relates to the ability of the publication to be accessed and recognized by the scientific community to which it is intended. The visibility of scientific journals can be assessed by two indicators: direct and indirect dissemination. Direct dissemination relates to the circulation of the publication, including the number of subscribers and its presence in libraries catalogs. Indirect dissemination is the presence of the journal in secondary sources, such as directories of journals, databases, and the internet. ${ }^{3}$

The inclusion in databases is essential to ensure the projection and visibility of scientific journals, as well as of the content they bring and researchers who publish it. Taking into account the importance of the presence of scientific journals in databases, our analysis focused on indirect diffusion, particularly in the presence of the target journals in national and international recognized and prestigious databases.

The responsibility of developing procedures to ensure that health journals are indexed in prestigious databases and satisfy editorial quality criteria is of publishing groups, who are responsible for editing such journals. Editors, particularly the editor-in-chief, play an essential role in the guidelines established for the quality and visibility of journals, as well as in inciting methodological and empirical innovation. ${ }^{4}$

Based on the perception of the importance of visibility of the scientific knowledge produced in the area of health, we sought to investigate the situation of 46 Portuguese scientific journals in the area of health. The main objective of the research is to verify the relationship between the editorial quality of the population of Portuguese health scientific journals and the national and international visibility of these journals.

\section{METHODS}

The study can be classified as analytical and cross-sectional, essentially quantitative, based on the analysis of compliance with the Latindex criteria for editorial quality of a population of Portuguese health magazines and the verification of national and international visibility of these journals.

This study took place between 2012 and 2018 . The selection of Portuguese scientific journals, with active state, from the health area, was performed on the Ulrich's International Periodicals Directory database, in November 2013.
The study population comprises 46 Portuguese scientific journals in the area of health that are active on the Ulrich's International Periodicals Directory. Between February 2014 and November 2015, we proceeded to research data related to the exhaustive check of compliance with the Latindex criteria for editorial quality of all issues of the years 2012 and 2013 of the journals selected in our study. The visibility of those journals was examined in the same period. By checking their indexing in the Index of Portuguese Medical Journals and SciELO Portugal, we investigated their national visibility. The international visibility was measured by checking their indexing in the Journal Citation Reports, the Medicus/MEDLINE Index, the Latindex System, and the SCImago Journal and Country Rank.

The results obtained from the data search were subsequently analyzed quantitatively. The statistical analysis of the data was done in Microsoft Excel, version 14.0 (32-bit) of Microsoft Office Professional Plus 2010.

\section{RESULTS}

The journals analyzed are mostly of quarterly periodicity; they are predominantly of the areas of Clinical Psychology, Nursing, Internal and General Medicine, Psychiatry, Cardiology and Cardiovascular Systems; the main publication language is Portuguese; the place of publication is mainly the district of Lisbon; the entities responsible are mostly scientific/professional societies; the creation dates are mainly between the years of 1994 and 2011; most journals have an electronic edition with free access to full texts and online presence.

The results of the investigation regarding compliance with the Latindex criteria for editorial quality is presented in Table 1.

TABLE 1. AVERAGE OF COMPLIANCE PER TYPE OF LATINDEX CHARACTERISTICS PER POPULATION OF JOURNALS ANALYZED

\begin{tabular}{l|l}
\hline Compliance with Latindex characteristics by the journal population \\
\hline Type of characteristics & $\%$ of compliance \\
\hline Basic characteristics & $99.7 \%$ \\
\hline Presentation characteristics & $85.0 \%$ \\
\hline Editorial management and policy characteristics & $90.6 \%$ \\
\hline Content characteristics & $86.6 \%$ \\
\hline Average & $91.0 \%$
\end{tabular}


The analysis of the circulation of the journals on the Index of Portuguese Medical Journals and SciELO Portugal databases allowed us to conclude that the average circulation is higher in the Index of the Portuguese Medical Journals, 46\%, in comparison with SciELO Portugal, with an average circulation of $26 \%$. The circulation of the journals on international databases was measured by checking their indexing on the Journal Citation Reports, the Medicus/MEDLINE Index, the Latindex System, and the SCImago Journal and Country Rank databases. The average circulation of the journal population is higher in the Latindex System, reaching $43 \%$. Immediately next is the SCImago Journal and Country Rank, in which the journals circulate, on average, $15 \%$. The two international databases with the lowest circulation were the Journal Citation Reports and the Index Medicus/MEDLINE, both with an average circulation of only $7 \%$.

In Table 2, we can see the average compliance with the Latindex criteria for editorial quality of all journals studied, as well as the visibility of each. The findings allow us to affirm that the degree of visibility of the population of Portuguese health journals, in national databases, is superior to that in international databases.

Based on the scatter plot of Figure 1, we see that the value of the linear correlation of Pearson's $r$ coefficient between the variable of editing criteria and the variable of visibility is $r=0.39$. For Pestana and Gageiro $^{5}, \mathrm{r}$ values between 0.2 and 0.39 indicate a weak positive linear association. According to these figures, we find there is a weak positive correlation between the variable of editing criteria and the variable of visibility.

FIGURE 1. SCATTER PLOT OF THE AVERAGE COMPLIANCE WITH THE EDITING CRITERIA AND AVERAGE VISIBILITY OF THE POPULATION OF JOURNALS

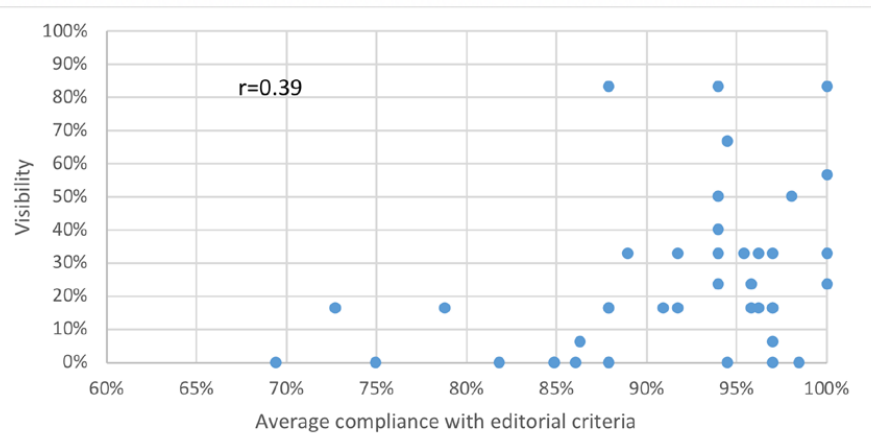

TABLE 2. AVERAGE COMPLIANCE WITH THE EDITING CRITERIA AND AVERAGE VISIBILITY OF THE POPULATION OF JOURNALS

\begin{tabular}{|c|c|c|}
\hline Journals & $\begin{array}{l}\text { Average } \\
\text { compliance } \\
\text { with edito- } \\
\text { rial criteria }\end{array}$ & Visibility \\
\hline Acta Médica Portuguesa & $100 \%$ & $83 \%$ \\
\hline Acta Obstétrica e Ginecológica Portuguesa & $79 \%$ & $17 \%$ \\
\hline Acta Pediátrica Portuguesa & $100 \%$ & $23 \%$ \\
\hline Acta Reumatológica Portuguesa & $88 \%$ & $83 \%$ \\
\hline Acta Urológica Portuguesa & $97 \%$ & $17 \%$ \\
\hline Análise Psicológica & $94 \%$ & $50 \%$ \\
\hline Angiologia e Cirurgia Vascular & $94 \%$ & $50 \%$ \\
\hline Archives of Exercise in Health and Disease & $86 \%$ & $0 \%$ \\
\hline Arquivos de Medicina & $94 \%$ & $67 \%$ \\
\hline Cadernos de Saúde & $88 \%$ & $0 \%$ \\
\hline Experimental Pathology and Health Sciences & $69 \%$ & $0 \%$ \\
\hline Factores de Risco & $73 \%$ & $17 \%$ \\
\hline GE - Jornal Português de Gastrenterologia & $94 \%$ & $40 \%$ \\
\hline Jada & $88 \%$ & $0 \%$ \\
\hline JETVCE & $85 \%$ & $0 \%$ \\
\hline Laboratório de Psicologia & $96 \%$ & $17 \%$ \\
\hline Medicina Interna & $94 \%$ & $23 \%$ \\
\hline Nascer e Crescer & $98 \%$ & $50 \%$ \\
\hline Nursing & $97 \%$ & $7 \%$ \\
\hline Oftalmologia & $88 \%$ & $17 \%$ \\
\hline Pensar Enfermagem & $92 \%$ & $17 \%$ \\
\hline Psicologia, Educação e Cultura & $97 \%$ & $17 \%$ \\
\hline Psicologia & $95 \%$ & $33 \%$ \\
\hline Psicologia, Saúde \& Doenças & $89 \%$ & $33 \%$ \\
\hline Psi Logos & $92 \%$ & $33 \%$ \\
\hline Psique & $98 \%$ & $0 \%$ \\
\hline Psychologica & $91 \%$ & $17 \%$ \\
\hline Revista de Enfermagem Referência & $97 \%$ & $33 \%$ \\
\hline Revista de Psicol. da Criança e do Adolescente & $97 \%$ & $0 \%$ \\
\hline Revista E-Psi & $96 \%$ & $17 \%$ \\
\hline Revista Investigação em Enfermagem & $97 \%$ & $17 \%$ \\
\hline Revista Motricidade & $100 \%$ & $57 \%$ \\
\hline Revista Portuguesa de Cardiologia & $94 \%$ & $83 \%$ \\
\hline Revista Portuguesa de Diabetes & $88 \%$ & $17 \%$ \\
\hline $\begin{array}{l}\text { Revista Portuguesa de Endocrinol. Diabetes e } \\
\text { Metab. }\end{array}$ & $96 \%$ & $23 \%$ \\
\hline Revista Port. de Enfermagem de Saúde Mental & $100 \%$ & $33 \%$ \\
\hline Revista Portuguesa de Farmacoterapia & $88 \%$ & $17 \%$ \\
\hline Revista Portuguesa de Grupanálise & $75 \%$ & $0 \%$ \\
\hline $\begin{array}{l}\text { Revista Port. de Hipertensão e Risco } \\
\text { Cardiovascular }\end{array}$ & $73 \%$ & $17 \%$ \\
\hline $\begin{array}{l}\text { Revista Portuguesa de Ortopedia e } \\
\text { Traumatologia }\end{array}$ & $96 \%$ & $33 \%$ \\
\hline Revista Sinais Vitais & $86 \%$ & $7 \%$ \\
\hline Salutis Scientia & $94 \%$ & $0 \%$ \\
\hline Sinapse & $94 \%$ & $33 \%$ \\
\hline The Lancet Infectious Diseases & $85 \%$ & $0 \%$ \\
\hline The Lancet Neurology & $82 \%$ & $0 \%$ \\
\hline The Lancet Oncology & $85 \%$ & $0 \%$ \\
\hline Total / \% & $91 \%$ & $24 \%$ \\
\hline
\end{tabular}




\section{DISCUSSION}

This is the first study to date, in Portugal, which relates the compliance with editorial criteria for quality with the national and international visibility of journals in the area of health.

A study conducted in Spain by Vázquez-Valero et al. ${ }^{6}$ that analyzed 275 Spanish journals of health sciences in relation to the Latindex criteria of editorial quality shows a compliance rate of $78.5 \%$.

The research developed by Abejón-Peña and Rodríguez-Yunta ${ }^{7}$ evaluated the results and benefits for Spanish journals of Spain participation on Latindex. The criterion relating to the indication of the dates of receipt and acceptance of the originals is identified as one of the least met by Spanish scientific journals. The same criterion is also one of the least met by the Portuguese journals analyzed: only $41 \%$ of printed journals and $56 \%$ of electronic ones met the criterion concerning the indication of dates of receipt and acceptance of the originals.

Another study conducted in Mexico by Alonso-Gamboa et al. ${ }^{8}$ on the contribution of Latindex to the characteristics and editorial quality of Mexican journals showed that the criterion relating to the indication of the dates of receipt and acceptance of the originals is among the less often met characteristics.

The investigation by Ponce-Aura9 ${ }^{9}$ on the circulation of Spanish biomedical journals on national and international databases concluded that Spanish medical journals have considerable circulation on national and international databases.

The results obtained in the study by Colombo ${ }^{10}$ on the visibility of 59 Argentinean journals of medicine on international databases found that 45 journals are indexed in multidisciplinary, international databases, but only three are indexed in the Web of Science, and five on Medline.

We found that the results of the research are similar to the data from similar studies from other countries that are part of the reference literature. Despite the high compliance with the Latindex criteria for editorial quality, the journals demonstrated reduced indexation in international databases, which reduces the international visibility of their articles.

\section{CONCLUSION}

The study demonstrated that the hypothesis that the editing criteria relate to the visibility of a population of Portuguese scientific health journals is confirmed.

Among the printed journals, the criteria most often not met are: the criterion relating to the indication of the dates of receipt and acceptance of the originals, met by only $41 \%$ of the journals; and the criterion regarding the indication of the institutional affiliation of the members of the editorial board, met by $48 \%$ of the publications. Both criteria are related to the presentation characteristics in the Latindex System.

The criteria less often met by electronic journals are: the criterion which requires an editorial opening, only $46 \%$ of these journals follow this guidance; the criterion relating to the indication of the dates of receipt and acceptance of the originals, met by $56 \%$ of electronic publications; the characteristic of provision of value-added services, met by only $62 \%$ of the publications; and the presence of search engines, met by only $69 \%$ of these journals. These criteria are related to the characteristics of management and editorial policy, characteristics of presentation, and characteristics of content, respectively.

Three journals stood out for registering, simultaneously, an average of compliance with the Latindex criteria for editorial quality above $75 \%$ and average visibility greater than $75 \%$ : The Acta Médica Portuguesa: the scientific journal of the Order of Physicians; and the Revista Portuguesa de Cardiologia: official publication of the Portuguese Society of Cardiology; and the Acta Reumatológica Portuguesa.

Despite the high compliance with the criteria for editorial quality, the international visibility of the journals analyzed is still scarce, which leads us to consider the need for developing complementary skills that connect several factors, such as the professionalization of editorial management, the attractiveness of the journal, and the development of criteria for scientific quality.

\section{RESUMO}

OBJETIVO: No âmbito das ciências da saúde, as revistas científicas desempenham um papel fulcral, contribuindo - para além da divulgação dos resultados científicos - para o progresso da medicina e para a formação dos investigadores. A visibilidade da produção científica é fundamental para o desenvolvimento da medicina. O objetivo deste estudo foi averiguar a relação entre a qualidade editorial de uma população de revistas portuguesas científicas de saúde e a visibilidade nacional e internacional destas. 
MÉTODOS: Estudo transversal analítico e essencialmente quantitativo, baseou-se na análise do cumprimento de critérios de qualidade editorial Latindex de uma população de 46 revistas científicas de saúde portuguesas e na verificação da respectiva visibilidade nacional e internacional.

RESULTADOS: A investigação revelou que a média global de cumprimento de critérios pela população de revistas situa-se nos $91 \%$. A visibilidade média da população é de $24 \%$. Confirma-se a hipótese de que os critérios de edição se relacionam com a visibilidade de uma população de revistas científicas de saúde portuguesas.

CONCLUSÃO: Apesar do elevado cumprimento de critérios de qualidade editorial, a visibilidade internacional das revistas analisadas é ainda escassa, o que aponta a necessidade de serem desenvolvidas competências complementares.

PALAVRAS-CHAVE: Publicações periódicas como assunto. Publicações científicas e técnicas. Saúde. Portugal.

\section{REFERENCES}

1. Donato H. Publicações médicas nacionais: passado, presente e futuro. Med Interna. 2015;22(1):5-7.

2. Revés J, Silva BM, Durão J, Ribeiro NV, Lemos S, Escada P. Predatory publishing: an industry that is threatening science. Acta Med Port. 2018;31(3):141-3.

3. Román-Román A, Giménez-Toledo E, Gómez-Caridad I, Martín-Sempere MJ, Páez-Mañá |, Román-Román A, et al. La edición de revistas científicas: guía de buenos usos. Madrid: Centro de Información y Documentación Científica; 2001.

4. Potvin L, Di Ruggiero E. Scientific journals commit to promoting population health intervention research. Can | Public Health. 2016;107(6):e489-91.

4. Pestana MH, Gageiro JN. Análise de dados para ciências sociais: a complementariedade do SPSS. $6^{a}$ ed. Lisboa: Edições Sílabo; 2014.

5. Vázquez-Valero M, Urdín-Caminos $C$, Román-Román A. Las revistas españolas de ciencias de la salud frente a los criterios de calidad editorial Latindex. Rev Esp Doc Cient. 2003;26(4):418-32.
6. Abejón-Peña T, Rodríguez-Yunta L. La participación española en Latindex valoración de resultados e impacto sobre la calidad y evaluación de las publicaciones científicas. Ci Inf. 2015;44(2):258-75

7. Alonso-Gamboa JO, Reyna-Espinosa FR, Sánchez-Islas LA. Características y calidad editorial de las revistas científicas mexicanas: la aportación de Latindex. Ci Inf. 2015;44(2):276-89.

8. Ponce-Aura C. Análisis de la circulación de las revistas biomédicas Españolas en bases de datos nacionales e internacionales [Tese de doutoramento]. València: Universitat de València Servei de Publicacions; 2004 [consultado 2015 Jun 12]. Disponível em: Universitat de València - Departament d'Història de la Ciència i Documentació http://www.tesisenred.net/bitstream/handle/10803/9980/ponce.pdf

9. Colombo F. Visibilidad de las revistas argentinas de medicina en las bases de datos internacionales. Inf Cult Soc. 2009;20:41-62. 